\title{
CHALLENGES OF DEMOCRACY IN NIGERIAN LOCAL GOVERNMENT SYSTEM: A CRITICAL ANALYSIS
}

\author{
Sheriff Ghali Ibrahim, Farouk Ibrahim Bibi-Farouk \\ and Aliyu Isa Binmohammed \\ Department of Political Science and International Relations, University of Abuja, \\ Abuja-Nigeria
}

Email: sherfboy@yahoo.com; Phone: +234-706-337-2013

\section{Cite this article:}

Sheriff G.I., Farouk I.B., Aliyu I.B. (2021), Challenges of Democracy in Nigerian Local Government System: A Critical Analysis. Journal of Advanced Research and Multidisciplinary Studies 1(1), 118-128. DOI:

10.52589/JARMS-BJXQ8P44.

\section{Manuscript History}

Received: 7 Dec 2020

Accepted: 30 Dec 2020

Published: 11 Aug 2021

Copyright $\odot 2020$ The Author(s). This is an Open Access article distributed under the terms of Creative Commons AttributionNonCommercial-NoDerivatives 4.0 International (CC BY-NC-ND 4.0 ), which permits anyone to share, use, reproduce and redistribute in any medium, provided the original author and source are credited.
ABSTRACT: After two decades of the return to civil rule, the not too impressive scorecard of Nigerian democracy has raised concerns and questions demanding answers as to why the country is still struggling with the delivery of democratic governance and dividends such as; social welfare, justice, evenfederal development as well as equal access to national resources. The paper inspects carefully, those factors that have and are hindering the success of democracy and democratic governance in Nigeria especially at the local government level. In doing this, related literatures were reviewed while the Structural Functionalist theory is adopted as the theoretical model or frame work and the collection of data was carried out through the secondary source. The study reveals that democracy in Nigeria especially at the local government level has not done up to its expectation due largely to corruption, partisan politics, upper governmental interference, lack of local government autonomy, among others. It therefore recommends that among other things, the local governments should be granted it constitutional autonomy in powers and functions, the fight against corruption should be stretched to the local government areas while Local government officials are made accountable to the local residence and that the leaders should be more ethical in their political pursue.

KEYWORDS: Challenges, Democracy, Local, Government, System, Nigeria 


\section{INTRODUCTION}

The local governments in theory are generally accepted as viable instruments in the democratization of modern governments as it makes for easy grassroots political participation and socialization. Its idea as scholarly presented, represent the most effective means through which democracy and democratic dividends are effectively delivered for the benefit of the masses at the grass root. Fundamentally, the Local Government is primarily out there to promote the spirit of local self-help and self-reliance, community sense of unity, national engagement, and achievement of development through a network of grass root participation and civil society organizations which connotes the basic tenets of democracy as a system of government. This is in agreement with the submission of Nwanna (2015) for instance, that the essence of local government is the consolidation of democratic values at the grass root. In his argument, the Local government is an instrument through which democracy and democratic political culture is or are established, nurtured and sustained such as grassroots political participation and socialization (Nwana, 2015).

However, the not too impressive scorecard of Democracy in Nigeria has invariably made the Nigerian experience of local government as well as local democracy very disappointing. After several attempts at democratization, the country is yet to evolve a viable, virile and stable democracy, not even at the local level that will elicit popular support or even have direct bearing on the lives of the ordinary people as the country is unarguably still struggling with the delivery of democratic governance and dividends such as; social welfare, justice, infrastructural as well human development and equal access to national resources among others. The most fundamental weaknesses of local governance in Nigeria are non-delivery, lack of accountability and corruption. Also is the failure of the institution of local government to enhance its capacity, to engage and mobilize the people and respond to their needs, and to administer effectively and responsibly the various local services

\section{Conceptual Clarifications}

Democracy: The term democracy as a governmental system is defined as the government where the people govern themselves thereby being the government of their own that administers their own affairs for their own benefits. This is capture in the popular definition of Lyncoln where he submitted that democracy was or is the government of the people, by the people and for the people. It is that form of government that operates base on the rights of the citizens to elect among competing ideologies, parties, politicians and people of their own choice to represent them in the processes of policy formulation and decision making. Or simply put it, that it is the governmental system that is based on the consent of the people.

Local Government: The Local Government is popularly known and refers to as the last tier of government and the third one, in Nigeria and other federal settings that operates three levels of government. It is an independent level of government established by the constitution that operates interdependently with the higher levels of government especially the state, in the exercise and discharge of its constitutional powers and functions. Popular among the definition of Local Government is the submission of Anifowose and Enemuo (2008) that Local Government is the lower level of government in modern state that is legally distinct and has powers to raise revenue and undertake constitutionally assigned responsibilities under a leadership that is elected and answerable to the local population. 
Challenges: The word challenge connotes huddles that interfere negatively in the affairs of individuals, group, or even a government and is capable of stopping or making impossible such activity. We can also refer to challenges as those obstacles, constraints and difficulties that hinder the smooth running or execution of any activity or activities. Hence in the context of this paper, it simply can be defined as those constraints that hinder democratic process and governance in Nigerian Local Government.

\section{LITERATURE REVIEW}

The popularity of democracy as a form of government has made many writers go into researching why democracy in Africa and Nigeria in particular, have or is not providing developmental results. David (2006) identified the conduct of election as a major challenge of democratization in Nigeria. According to him, democracy and every benefit that is accrue to it, is not been enjoyed in Nigeria mostly because the political class have been unable to conduct a general election to successfully transit power from one civilian administration to another that have been adjudged to largely be free from frauds which constantly generates unnecessary national controversy. In the same vein, Ken (2008) faulted the Nigerian electoral process as well as the electorates and most especially the political leadership who assume power base on consensus as against the democratic criteria of popularity, for their lack of development will.

Using the core characteristics of democratic governance as acknowledged by the UNDP through the report of her Governance for Sustainable Human Development (GSHD) agency to include; Participation, Rule of Law, Transparency, Responsiveness, Equity, Accountability and Strategic Vision (UNDP, 2007) among others, Adeyemi (2012) opined that democratic governance in Nigeria was a mirage on the account of the absences of the above highlighted features. In his words, as against the report of the Governance for Sustainable Human Development (GSHD), the UNDP acknowledged characteristics of good democratic governance were glaringly deficient in governance, even during the democratic reign, thus making good governance as an element of constitutional government to be in its infancy in Nigeria (Adeyemi 2012).

Corruption has also been identified by a number of scholars as a major bane to the prospect of Nigerian democracy and democratic process. Defined as the offer and receipt of undue advantage or the prospect there of; corruption results to the distortion of proper performance of any duty, due process and or behavior required of the recipient of bribe or the undue advantage directly or indirectly (Kofele-Kale 2006). As a structure or tier of government, the Local Government is popularly seen as the last and closest unit of government through which the people easily participate in the process of administering and making decisions that affects them. The Encyclopedia (1975) defined Local Government as the smallest sub-division of a country's territory and population with such features including; continuing organization, the powers to undertake public activities, enter into contracts, the right to sue and be sued, and the ability to collect taxes and determine budget.

In the submission of Adrian (1972), the functions performed by the Local Government are local or domestic to the area and people. According to him, the Local Government is a subdivision of national or regional government constituted by law, which performs functions 
that are defined as "local", with the powers to generate revenue including tax, and a degree of discretion in the making of decisions that are free from higher governmental control. Common, in the scholarly submissions on local government is that it is the administration of a locality, a village, a town, a city or any other area smaller than the state by a body representing the local inhabitants, possessing a fairly large amount of authority, raising at least a part of its revenue through local taxation and spending its income on services which are regarded as local and therefore, is distinct from state and central services.

\section{Theoretical Frame Work}

The Structural Functionalist theory is adopted to support our explanation of the role or function(s), the local government as an independent level of government has to perform for the survival of Nigeria's democratic federal setting as provided by the constitution, whose failure over the years has form a part of the impediments of democracy in Nigeria. Structural functionalism as presented by scholars popular among them, including Gabriel Almond and Talcott Persons is a theory that looks at the political system as a coherent whole with structures which performs certain functions interdependently and are only meaningful in terms of the working of the whole system. According to Almond, the political system must perform some set of tasks for the survival and the functional requirement of the system to be performed by different kinds of political structures (Almond, 1956). Central to the functionalist theory, is the assumption that all societies survive on the performance of some certain functions by designated structures and as such, the foci of attention in the approach is or are the structures and then the functions they performs. And in the discussion of local government as a level of government, the local government is seen as a structure in the society with definite functions (Maidoki and Philip, 2009).

Hence, using the functionalist theory, it will help us in describing and understanding the local government as a structure or instrument through which certain basic democratically designated functions of the society as a whole is to be administered locally base on the intimate knowledge of the needs, conditions and peculiarities of the areas concerned.

\section{Local Government as an Agent of Democratic Governance}

The democratic local governments are characterized with such features/functions like; political training ground, agents of Local participation, link between the grass root and the upper government, Autonomous Status, e t c.

It brings government nearer to the people: Central to the democratic local governments is the feature that it actually draws government and governance to the grass root. The local government in all settings irrespective of the variations in locality and governmental structures or formation, is the last tier of government which is invariably the closet to the citizens in terms of the services it renders and the accessibility to government official by citizens. According to Oladesu (2014), the local government represents the third tire of government that is charged with the responsibility of bringing government closer to the people. In essence, the dividend of democratic governance is brought among the people's reach as they are assisted by local government toward accessing and enjoying government facilities. 
Agent of political education: The success and sustainability of democracy is partly imbedded or hinged on the level of people's awareness and how educated they are about political leaders, institutions and government policies. This makes it important that the electorates of democracy as posited by are Mashall (1965), are equipped with the knowledge of such basic element that determines the working of the system. According to him, is required of the "voters" to know such things like how to; identify the inaccurate demagogue of government, learn to avoid voting for or voting out incompetent or corrupt representatives, be educated on the how and important of healthy and effective debate on government agendas/policies, learn to think for the future during election and in the cause of making demand or supporting the system as well as have the ability to establish the relationship between the expenditures and revenue of government (Marshall, 1965). Hence in pursued of the above, the closet and most accessible level of government to the people, which is the local government becomes fundamental to the mobilization and political education of the masses.

Leadership training ground: The local government by the virtue of her strata in the hierarchy of government organogram especially in democracies, and the constitutional provisions from which she derives her powers and functions, is the basic foundation of political leadership training particularly for those individuals who intent to further prosper their career in national politics. According to Wilson (1984) the ultimate purposes of the local government is political education which revolves around education on the use of power and authority and in the risks of power as well as versatility and the ability to solve difficult problems. The organization and specification of the powers and functions of democratic Local government is designed in a way that it is able to initiate and develop leadership potentials in the people from the grassroots. As a result, through the people's participation at the local level in the management of their own affairs, they acquire necessary experience and capability to handle bigger affairs later at the state or national level.

Accountability: On the accountability of government, the democratic local government is also designed to give the people at the grass root the control over government officials. As a result, the local government being a last layer of government even though a subordinate to the state and federal governments, is largely and directly accountable to the locality and not the state or federal government, except on some legislative matters. As argued by Mill (1975), not only are separate executive officers (local government) required for purely local duties, but the popular control over those officers can only be effectively exerted through the locals. Their original appointment (election), the function of watching and checking them, the duty of terminating there tenure or continuity and the physical support necessary for their operation, should rest with the people of the locality.

The argument of Adebayo (2014) is that local accountability can only be best achieved if it is directed towards the locality since the local government exists solely for the service of the local people as it provides services of local nature called social amenities like sanitation, education, transport etc. to the people of the area. In general perspective, local government is viewed as a means of ensuring government accountability, through such democratic activities within the local government, such as elections, rule formulation, public debates, accessibility that bridges the gap between the citizens and their responsible administration, as well as the provision of opportunities for the handling of grievances. 
Political Participation: Imperative for local government as the nearest government to the people and the government that is locally administered by the local, is the people's input through direct or indirect participation in decision making which according to Obamwonyi and Aibieyi (2015), manifests through regular town hall meetings, composition of functionaries, and general staffing. Therefore, the local government because of its closeness to the electorate and her scope of operation is an instrument through which apathy that would have evolved owing to the difficulty usually encountered by people in national and state politics in terms of participation is curtailed, as it (the local government) affords them the opportunity to participate in public affairs, there by fostering a sense of belonging among them.

Legal and Autonomous Status: The democratic local government is naturally entitled to enjoy Legal status by the virtue of its creation through a legislative process. In Nigeria, the 1999 constitution as amended recognizes the status of local government in the country as a unit/level and not the extension of either the federal or state government. Similarly, the autonomy of local governments is a natural fall-out of its legal status and the statutory process that creates it. As a legal entity, its powers, functions and relationship with both central (federal) and state governments are clearly stated in the constitution.

\section{FINDINGS AND DISCUSSION}

\section{Poor Political Process}

The absence of sound and participatory political activities in the local government is its self a great challenge of democracy in Nigeria. Though not given much attention, however a viable political process is a great requirement for an efficient local democracy and whose absence is the source of the other impediments since the concept of democracy itself revolves around politics with the participation of the populace. This was aptly observed by Olowu and Wunsch as far back in the 90s when they argued that a substantial decentralization effort in Nigeria during the later 1980s and early 1990s were weakened by the absence of viable local political processes to convey information to the public about government decisions, to organize publics to be attentive to government actions, to mobilize public opinion regarding local government, and to hold local officials accountable for their performance. Hence in their words, the absence of attentive local publics and of close linkages between officials and citizens appeared to explain many of the problems found in local governmental performance in Nigeria (Olowu and Wunsch, 1996).

Usually, a viable local political process includes an active civil society, some general political organizations (e.g., factions, parties or their surrogates), a sound legislative arena, laudable opinion leaders and their publics, and the mechanisms to gather and spread information which in the argument of Ziblatt (2020) can only be best ensured by a decentralization arrangement that encompasses (de-concentration) of resources and personnel, and (devolution) of authority. Furthermore, is the development of a viable local electoral process that is participatory and ensures government accountability to the constitution, the political party and the electorate as a means of enhancing representation.

Lack of Local Government Election: In Nigerian local government, a major setback for democracy has been the challenge of local government election as an activity and or a 
process. At first, the federal government itself in 1999, impeded against local democracy as it failed to conduct a general election for the third tier of government despite the visible unification of local government in the constitution there by living them to the mercy of the state governments. At the expiration of local government council's tenure in May 2002, most if not all the state governors exploited the repeated postponement of local government election to appoint transition or 'caretaker' committees except the F.C.T.

The postponement continued courtesy the June 2003 federal government announcement that the system of local government administration would be subjected to a wide-range review which sanctioned the indefinite suspension of local government election. Consequently, as observe by Ugborgu (2012), as a "norm", most state governors continued to refuse to conduct local government elections at will, and in the cases where they are conducted, the ruling party at the states arbitrarily dominates the process while denying other parties the opportunity to effectively participate. Hence, since 1999 till date, there had never been a period where we have had all the 774 local government chairmen democratically elected. Popular of such instance of refusal is Anambra state where the governors refused to conduct local government elections for over ten years (Akaeze, 2012).

Electoral Fraud: Closely related to the challenge of non conduct of Local Government election as argued by Adejuwon and Akanni (2018), is that in the instances where the elections are conducted, the process is crowded by electoral malpractices ranging from intimidation to other form of violence to facilitate rigging and the ruling party's domination facilitated by their Governor "Godfathers." A reported of the Human Rights Watch (2004) indicted either the state or local government officials of the involvement in several cases of violence against their perceived opponents during the 2004 elections; a situation which has continued till date. According to the report, electoral crises involving killings and other types of violent clashes were recorded by election observers, journalists and other sources by the end of March 2004 in at least 22 out of Nigeria's 36 states of the federation (Transition Monitoring Group (TMG), 2004; Daily Champion, 2004 and Associated Press, 2004). For instance, 2004 local government elections were cancelled in Delta state out of the fear that elections would aggravate ongoing violence (TMG 2004). From 2007 onward, a popular case of violence during local government election is the 2008 clashes between the Hausa-Fulani "settlers" who are predominantly Muslims and the "indigenes" of Jos-Plateau State, who are predominantly Christians after the local government elections that produced a Muslim Hausa Chairman (International Crisis Group, 2012). Very interesting is the fact that this electoral violence is prevalence in almost all states of the federation including the FCT with instance like the 2015 APC primary election crises that left uncountable party members injured.

Political interference: Another challenge of democracy as observed by Osahon and Walter (2017), and particularly local democracy in Nigerian is the unconstitutional interference in the affairs of Local government by "higher" governmental levels especially the state which threatens her (local government) existence and effective performance as a unit of government in the country. Despite it recognition as an independent level of government, the third tier of government in the argument of Shamsuddin and Bala (2014), have been kept under the undue control of state governments through such policy choices and strategies including fiscal or juridical bureaucratic hostility and weakness as well as the absence of complimentary reforms needed in national or state administrative law and systems. Another form of unconstitutional interference and control of local government especially by the State governors is the dissolution of local government officials at will. In the reports of Maduabuchi, Akinsuyi, and 
Opesetan (2014), some of the states where the governors arbitrarily dissolved local government include; Ondo State in 2008, Ekiti State in 2010, Imo State in 2011, and the indefinite suspension of 11 local government chairmen of Rivers State in 2012.

Local Government Autonomy: Another factor that threatens or hinders local democracy in Nigeria is the issue relating to the autonomy of local government as a level of government. The local government is strongly argued to seriously lack in reality, the autonomy constitutionally accrued to it in the management of its affairs and appropriation of funds as such power is being absolved by the states through "de-concentration" which Cohen and Peterson (1996) explained it to essentially entails the redistribution of central resources to localities with tacit acquiescence to those central authorities. A situation where against its independent status, the local governments have no direct access to her share of federal allocation and acts largely as the agents of state governments in expending resources allocated to them by higher government authorities and the management of personnel.

Using a number of technicalities, the state government hides under Section 7 (1) \& (6) of the 1999 Constitution as amended, to hijack the local governments power of financial appropriation through funds and institutions including; funds for joint state and local government projects, funds for provision of infrastructural facilities through the state government offices of local government affairs, the ministry of local government, and the local government service commission (Akaeze, 2012). More also just as argued by Otinche (2014), not until it's abrogation in 2020 by federal government, the major instrument through which the local government autonomy is denied is the concept and practice of State and Local Government Joint Allocation Account for the receipt of federal allocations.

Local government Viability: Despite the explicit enumeration of sources of Local Government revenue by the 1999 constitution as amended beyond her share of the Monthly federally generated revenue, about $95 \%$ of Nigerian local government are not financially viable either because the local officials are unable to tap other source of revenue, or that revenue generation from other sources especially large markets are taking over by state governments (Ibok, 2014). Hence as observed by Chukwuemeka, Ugwuanyi, Okolo and Onuoha (2014) and Ezeani (2012), the financial resources directly available to LGs in Nigeria are grossly inadequate placed side by side it constitutionally assigned responsibilities and the societal expectations such as the unrestrained demand for fund by individuals and over ambitious expectations of the populace that commonly leads to the over bloating of council personnel structure.

Corruption: Corruption in Nigerian Local government is one of the fundamental problems of local democracy just as it is to the country as a whole where it has thrived, progressed and flourished unabated and as a result, in the argument of Adejuwon and Akanni (2018) it has helped to inculcate negative understanding of what democracy is as it is now looked at as an avenue that afford one the opportunity to milk out what he or she is able, from the state rather than collective participation in the development of the nation. As against effective and viable local democracy, it has breeds in a worrisome magnitude the menace of poor governance, inefficiency, and rises in cost of transaction, undermines institutions and hinders development which is central to the existence of Local Government (Ejike 2014).

Corruption in Local Governments just like other levels and agencies of government manifests through non-adherence to provisions of the financial memorandum (FM), conspicuous 
consumption and lifestyles of government officials that do not commensurate with their official sources of income, imposition of leaders on the local government through corrupted political process and low wages of local government staff (Ali, 2008). Other faces include outright falsification of financial transaction (payment for jobs not done), inflation of contracts and other financial transactions, existence of ghost workers, connivance with states' apparatus that are supposed to perform oversight functions, payment of huge sums of money to political godfathers and above all, lack of accountability.

\section{CONCLUSION}

The paper concludes that the challenges of democracy in Nigerian local government are both attitudinal and institutional as it has been established that state governors are the major impeding factors against democracy at the local level and by extension, local self-government in Nigeria. For democratic governance to thrive in Nigeria and the local government in particular, grass root participation must be encouraged and sustained, and Local Government officials be made accountable to the Localities and not the state governors. As such with sincerity, every other problem becomes surmountable as the overbearing attitudes of the state governors would have been curbed genuinely if the spirit of the 1999 Constitution is genuinely allowed to work

\section{RECOMMENDATIONS}

It is recommended that against the mere de-concentration of powers that is currently obtainable, devolution which has been favored as the most effective decentralization mechanism for the success of local democracy should be fully implemented in Nigeria. This is because it empowers the local government with its financial autonomy as an independent level as well as the freedom to make decisions and take action independently of central administrative oversight such as the authority to hire, fire, tax, contract, expend, invest, plan and set priorities.

To curb the challenge of local government non-viability and inadequate finance and to implement its programs, the economic base of the government at the local level should be developed through an upward review of the statutory allocations to local government while it is encouraged to develop or improve it Internally Generated Revenue (IGR) strength. This will invariably promote rural development, poverty reduction and inequality, and the stemming of excessive high rates of rural-urban migration

To stem corruption, the local government officials must be made to be accountable to the electorates and not state governors while the civil society constantly demand transparency and accountability from local government officials for the attainment of good governance for effective development at the grassroots level.

It is also important to note that the local government as a unit is better equipped with value system and democratic culture so as to make it a true democratic administrative system, real service providers, efficient decision makers, and dynamic grassroots transformers. It is also important to have improved mechanisms for active and maximal participation of local 
residents in local government affairs through involvement in not only election, but the initiation and implementation of the local government projects.

To curtail the challenge of the deliberate refusal of state governors to conduct local government election and to minimize the rate of electoral malpractices when conducted, it is recommended that the Third Schedule, Part II, that establishes the State Independent Electoral Commission, be expunged from the constitution and the functions be transferred to Independent National Electoral Commission (INEC). This does not imply that INEC has evolved as a credible institution but it shall minimize governors' imposition of Local Government political operatives.

\section{REFERENCES}

Adedire, S. A. (2014). Local Government and the Challenges of Rural Development in Nigeria (1999 to date). Journal of Humanities and Social Science, V. 19, 98-107.

Adejuwon, K. D., and Okewale, R. A. (2018). Challenges of Democracy and Development in Nigeria. International Journal of Social and Policy Issues7(1)

Adeyemi, O. (2012). Corruption and Local Government Administration in Nigeria: A

Discourse of Core Issues. European Journal of Sustainable Development, 1(2), 183-198. Adrian (1972). Encyclopedia of the Social science.

Akaeze, A. (2012). How the Local Governments are Robbed of Funds. Newswatch Magazine, April 2, p.15.

Ali, M. (2008) "Corruption Hinder Effective Council Administration". http://www. efccnigeria. org/index.

Almond, G.A. (1956). Comparative Political Science. Journal of Politics, Southern Political Science Association

Anifowose, R. and Enemuo, F. (2008). Element of politics, Lagos: Malthouse.

Appadorai A. (1975) the Substance of Politics. New York: Oxford University Press.

Chinwe, N. (2015). Governance and Local Government Elections in Nigeria's Fourth

Republic in Agbu, o. (2016). Election and Governance in Nigeria's Fourth Republic.

Oxford: African Books Collective.

Chukwuemeka, E., Ugwuanyi, B. I, Okolo, P. and Onuoha, C. E. (2014). Nigerian Local

Government: A Discourse on the Theoretical Imperatives in a Governmental System.

African Review, an International Multidisciplinary Journal, 8 (2) 305-324.

Cohen, J. and Stephen, P. (1996). Methodological Issues in the Analysis of Decentralization

Development. Discussion Paper No. 555. Harvard Institute of International

Development, Cambridge Mass.

Daily Champion (2004). Edo Still Boils Two Days After Local Government Poll, March 30.

Daniel Ziblatt (2020). Challenges to Democracy. Center for European studies, Harvard University.

David, K. (2006). Some Reflections on the Challenges of and Prospect of Democratization in Nigeria. Fulbright Alumni Association of Nigeria, Book of Reading No.2

Ejike, E. (2014). Leadership. Nigeria Ranks 136th Most Corrupt Country in Latest Global Corruption Index.http://leadership.ng/news /392876.

Ezeani, O. E. (2012). Local Government Administration in Nigeria. Enugu: Zik-Chuks

Printing Press. 
Federal Republic of Nigeria. (2011). 1999 Constitution of the Federal Republic of Nigeria as amended 2011. Lagos: Federal Government Printer.

International Crisis Group. (2012). Curbing Violence in Nigeria (I): The Jos Crisis.Crisis Group Africa Report.

James, S. W. (1998). Decentralization, Local Governance and the Democratic Transition in Southern Africa: A Comparative Analysis. Florida: African studies quarterly, Center for African Studies,

Kofele-Kale. (2006). The International Law of Responsibility for Economic Crimes: Holding State Officials Individually Liable for Acts of Fraudulent Enrichment. England: Ashgate Publishing Ltd

Lanre, A. (2012). The Challenges of Democratic Governance in Nigeria. International Journal of Business and Social Science 3(5)

Maduabuchi, E., Akinsuyi, T., and Opesetan, T. (2014). “Tenure: Local Governments' Triumph over Governors". Sunday Independent, 27th July, 15 - 17

Marshall, A. (1965). Financial administration of Local Government. George Allen \&Unwin, London.

Mill, J.S. (1975). Consideration on Representative Government, in his Three Essays (With an Introduction by Richard Wollheim). New York: Oxford University Press.

Oladesu, E. (2014). Fragile Councils Groaning under Fledging Federalism. The Nation, 25th February, 43-44

Olowu, D., and James, W. (1996). "Regime Transformation from Below: Decentralization, Local Governance and Democratic Reform in Nigeria. Studies in Comparative International Development, 3(4).

Osahon, O. and Walter, I. (2017). Democracy in Nigeria: Problems, Challenges and Consolidation, in Walter, I., and Momoh, L.R (eds), Democracy in Niggeria. Ekpoma: Ambrose Alli University press.

Otinche, S. I. (2014). Fiscal Policy and Local Government Administration in Nigeria. An International Multidisciplinary Journal 8 (2), 118-13744

Samson, E. and Obamwonyi, S. A. (2015). State Governors as Albatross to Democracy and Local Self-Government in Nigeria. Journal of Policy and Development Studies, 9(2).

Shamsuddin.B,SiddigBalal.I. (2014). Challenges of Local Government Administration in Nigeria: An Appraisal of Nigerian Experience. International Journal of Science and Research. 3(7)

Transition Monitoring Group (2004). 'Preliminary Report Issued on the Local Government Council Elections held on Saturday, March 27.

Ugborgu, V. (2012). "Tug of Politics" .Newswatch Magazine, 6th August, p.22.

UnitedNations Development Program. (2007). Governance for Sustainable Human Development, a UNDP Policy Paper

Wilson, C. F. (1948). The Foundation of Local Government, in his Essays on Local Government. Oxford: Basil Blackwell Press. 